\title{
ABSTRAK \\ ISOLAI DAN PENGUKURAN AKTIVITAS ENZIM BROMELIN \\ DARI EKSTRAK KASAR BATANG NANAS (Ananas comosus) \\ PADA VARIASI pH
}

\author{
Mashuri Masri, Dosen Jurusan Biologi, \\ Fakultas Sains dan Teknologi, UIN Makassar \\ E-mail: mashuriuin@ gmail.com
}

\begin{abstract}
Penelitian ini bertujuan untuk mengisolasi enzim bromelin dari batang nanas (Ananas comosus) dan mengukur protein dan aktivitas enzim bromelin dengan substrat gelatin pada variasi $\mathrm{pH}$. Hasil penelitian menunjukkan kadar protein tertinggi pada pengendapan dengan amonium sulfat $60 \%$ yaitu sebesar $37,785 \mu \mathrm{g} / \mathrm{ml}$ dan $\mathrm{pH}$ optimum aktivitas enzim bromelin yaitu pada pH 6,0 dengan nilai aktivitas 1,021 unit/gram.
\end{abstract}

Kata Kunci: Batang Nanas, Pengendapan, pH, Enzim Bromelin.

\begin{abstract}
ISOLAI AND MEASURING THE ENZYME ACTIVITY OF CRUDE EXTRACT OF BROMELIN STEMS PINEAPPLE (Ananas comosus) ON THE VARIATION OF pH
\end{abstract}

This research aims to isolate the enzyme bromelin from stems of pineapple (Ananas comosus) and measure protein and enzyme activity substrate bromelin with gelatin on a variation of the $\mathrm{pH}$. The results showed the highest protein levels in precipitation with ammonium sulfate $60 \%$ is 37,785 $\mathrm{g} / \mathrm{ml}$ and $\mathrm{pH}$ optimum bromelin enzyme activity at $\mathrm{pH} 6.0$ with value activity 704 units/gram

\section{Keywords: Stems Of Pineapple, Precipitation, Ph, Enzyme Bromelin}

Indonesia banyak dibudidayakan tanaman nanas karena merupakan salah satu negara yang beriklim tropis yang sesuai dengan syarat tumbuh dari tanaman nanas. Nanas merupakan tanaman buah berupa semak, dengan ujung daun dan tepi daun yang berduri dan memiliki tulang daun yang sejajar. Kemudian memiliki kulit yang berwarna 
hijau kekuning-kuningan, serta daging buah berwarna kuning (Hairi, 2010). Adapun klasifikasi dari tanaman nenas adalah sebagai berikut:

Divisio : Magnoliophyta

Classis : Liliopsida

Subclassis : Zingiberidae

Ordo : : Bromeliales

Familia : Bromeliaceae

Genus : : Ananas

Species $\quad$ : Ananas comosus (Gembong dalam Syamsiah, 2006).

Buah nanas yang sudah masak dapat dikonsumsi langsung sebagai buah segar dan yang dikonsumsi adalah bagian dagingnya saja, setelah dikupas kulitnya dan dibersihkan dari duri-durinya yang kemudian dicuci dan diberi garam, karena ada rasa getir dan cairannya yang kadangkala menusuk perut terutama bagi yang sakit lambung (maag) atau dalam bentuk buah-buahan kaleng. Sedangkan pada bagian batang, daun, kulit dan bonggolnya hanya dibuang begitu saja dan bahkan digunakan sebagai pakan ternak (Efendi et al, 2012).

Enzim bromelin merupakan enzim yang dapat menghidrolisis ikatan peptida pada kandungan protein menjadi asam amino. Enzim bromelin memiliki sifat yang mirip dengan enzim proteolitik, yakni memiliki kemampuan untuk menghidrolisis protein lainnya, seperti enzim rennin (renat), papain, dan fisin. (Christy, 2012). Enzim bromelin memiliki manfaat yang sangat banyak bagi kehidupan manusia yaitu dapat mendegradasi kolagen daging, sehingga dapat mengempukan daging (Utami, 2010), kemudian pada pengolahan VCO yaitu enzim bromelin menghidrolisis protein menjadi senyawa-senyawa yang lebih sederhana pada santan (Edawati, 2005). Sedangkan pada bidang kesehatan enzim bromelin dapat mengurangi rasa sakit dan pembengkakan karena luka atau operasi, mengurangi radang sendi, menyembuhkan luka bakar, serta meningkatkan fungsi paru-paru pada penderita infeksi saluran pernapasan (Kumaunang et al, 2011).

Selain itu enzim bromelin dapat melarutkan lendir yang sangat kental dalam sistem pencernaan, memecah lemak di usus sehingga membantu membersihkan usus 
dan saluran pencernaan. Mengurangi tekanan darah tinggi, mengurangi kadar kolesterol darah (membersihkan darah) dan mencegah stroke. Mencuci timbunan protein dan parasit cacing pada dinding usus sehingga dapat dengan mudah dikeluarkan melalui feces. Menghambat pertumbuhan sel kangker dan merangsang serta meningkatka sistem pertahanan tubuh (Indrawati, 1992).

Berdasarkan beberapa penelitian terdahulu diketahui bahwa nanas beserta limbahnya (batang dan kulit) dapat, menghasilkan enzim bromelin. Enzim ini dapat diisolasi dari daging buah, kulit buah, bonggol (hati), tangkai daun, dan daun (Suhermiyati et al, 2005). Enzim bromelin kasar hasil isolasi dari bonggol nanas mempunyai unit aktivitas 5,373 U/mL; kadar protein 10,299 mg/mL; aktivitas spesifik 0,521 U/mg; dan menurut (Wuryanti, 2006) berat molekul 33.500; titik isoelektrik dengan $\mathrm{pH}$ 9,55; $\mathrm{pH}$ optimum adalah 6-8; suhu optimum adalah $50^{\circ} \mathrm{C}$; dan aktivitas spesifik adalah 5-10 U/mg protein. Sedangkan pada kulit nanas memiliki kandungan enzim bromelin, dengan aktivitas optimum diperoleh pada temperatur $65^{\circ} \mathrm{C}$ sebesar 0,071 unit/menit dan pada pH 6,5 sebesar 0,101 unit/menit (Kumaunang et al, 2011).

Aktivitas bromelin optimum pada suhu $50^{\circ} \mathrm{C}$, di atas suhu tersebut keaktifan akan menurun. pH optimum 6,5-7 dimana enzim akan mempunyai konformasi yang mantap dan aktivitas maksimal (Fajrin, 2012). Menurut Gautam dkk (2010), enzim bromelin yang diisolasi dari buah dan batang nanas memiliki aktivitas yang berbeda. Aktivitas enzim bromelin dari batang lebih tinggi yakni 3,500 GDU/gram sedangkan enzim bromelin dari buah nanas hanya 1,500 GDU/gram. Berdasarkan beberapa hasil penelitian tersebut di atas maka diduga aktivitas enzim bromelin dari batang nanas juga memiliki aktivitas yang lebih tinggi di bandingkan bagian lain pada nanas. Dengan demikian penelitian ini dilakukan untuk mengetahui aktivitas optimum ekstrak kasar enzim bromelin yang diisolasi dari batang nanas. 


\section{METODE PENELITIAN}

Penelitian ini merupakan penelitian eksperimen yang bertujuan mengisolasi enzim bromelin dari batang nanas (Ananas comosus) dan mengukur aktivitas enzim bromelin dari batang nanas pada variasi $\mathrm{pH}$ untuk mengetahui $\mathrm{pH}$ optimumnya. Penelitian ini terdiri atas dua variabel adalah Variabel terikat yaitu aktivitas enzim bromelin dan Variabel bebas yaitu ekstrak batang nanas (Ananas comosus) berdasarkan variasi $\mathrm{pH}$.

Alat yang digunakan pada penelitian ini adalah pisau, baskom, kertas saring dan saringan, corong, tabung reaksi, rak, tabung, tabung epenndof, gelas kimia, blender (miyako), $\mathrm{pH}$ meter dan kertas lakmus, mikro pipet, tip, neraca analitik, timbangan, sentrifugasi (thermo scienfic haraeus labofuge 200 cenrifugasi 63:B5-2-3-16), kulkas, oven (memert B5-2-3-12), hot plate, vorteks, inkubator (thermo scienfic haraeus incubator B5-2-3-08) dan Spektrofotometer UV-VIS.

Bahan yang digunakan yaitu batang nanas, aquadest, natrium asetat $\left(\mathrm{CH}_{3} \mathrm{COONa}\right)$ 0,1 M pH 6,5, amonium sulfat $\left(\left(\mathrm{NH}_{4}\right)_{2} \mathrm{SO}_{4}\right)$ konsentrasi 10\%, 20\%, 30\%, $40 \%$, 50\% dan $60 \%$, gelatin $0,05 \mathrm{ml}$, reagen bradford, etanol $95 \%$, dan buffer fosfat $\left(\mathrm{H}_{2} \mathrm{PO}_{4}^{-}\right) 1 \mathrm{M} \mathrm{pH} 6,5, \mathrm{NaOH}, \mathrm{HCl}$, kertas saring dan indikator $\mathrm{pH}$ universal.

\section{Prosedur Kerja}

\section{Pembuatan Ekstrak Kasar Batang Nanas}

Batang nanas yang digunakan adalah batang yang berasal dari buah nanas yang mengkal, ditandai dengan warna kulitnya hijau kekuningan. Batang nanas dicuci dengan aquadest kemudian ditimbang sebanyak 750 gram. Selanjutnya dihomogenisasi dengan menggunakan $100 \mathrm{~mL}$ larutan buffer natrium asetat $\mathrm{pH}$ 6,5 kemudian disaring. Ekstrak kasar disentrifugasi selama 25 menit pada $3.500 \mathrm{rpm}$, dan disimpan pada suhu $4^{\circ} \mathrm{C}$.

\section{Pengendapan dengan Amonium Sulfat}

Penambahan ammonium sulfat berfungsi untuk mempresipitasi ekstrak kasar enzim bromelin, dengan konsentrasi masing-masing 10\%, 20\%, 30\%, 40\%, 50\% dan $60 \%$, sambil diaduk menggunakan pengaduk magnet atau di vorteks selama 45 menit, dan di inkubasi semalam di dalam kulkas. Selanjutnya, disentrifugasi pada $3500 \mathrm{rpm}$ 
selama 25 menit. Endapan yang dihasilkan dicuci dengan $10 \mathrm{~mL}$ buffer natrium asetat 0,1 M pada kisaran pH 6 - 6,5 dan dilakukan sebanyak 3 kali ulangan.

\section{Penentuan Kadar Protein Ekstrak Enzim Bromelin}

a. Penentuan kadar protein dilakukan dengan menggunakan metode Bradford, yaitu untuk mengukur konsentrasi protein total secara kalorimetri dalam suatu larutan. Dalam uji Bradford melibatkan pewarna Coomassie Brilliant Blue (CBB) yang berikatan dengan protein dalam suatu larutan yang bersifat asam sehingga memberikan warna (kebiruan). Dan absorbansinya diukur pada $\lambda 595 \mu \mathrm{m}$. Kadar protein ditentukan dengan membandingkan absorbansi ekstrak kasar enzim bromelin dengan kurva standar gelatin.

b. Pembuatan larutan standar gelatin yaitu dengan cara menimbang 0,01 g gelatin kemudian dilarutkan dengan $10 \mathrm{ml}$ aquadest steril sehingga diperoleh larutan stok gelatin pada konsentrasi 1000 ppm. Larutan stok pada konsentrasi 1000 ppm diencerkan dengan melarutkan 0,5 ml larutan stok ditambahkan 4,5 $\mathrm{ml}$ aquades steril sehingga diperoleh larutan stok gelatin 100 ppm. Dari larutan stok tersebut dilakukan pengukuran terhadap standar protein terlarut dengan konsentrasi 10, 20, 30, 40, 50 dan $60 \mathrm{ppm}$. Kemudian dilakukan pengukuran terhadap standar protein dengan menambahkan $0,005 \mathrm{ml}$ seri larutan standar dengan 2,5 $\mathrm{ml}$ reagen Bradford dan larutan tersebut divortex serta di inkubasi pada suhu ruang selama 10-60 menit. Larutan ini bersifat asam sehingga memberikan warna biru, kemudian selanjutnya diukur absorbansinya pada $\lambda 595 \mathrm{~nm}$.

c. Pengukuran absorbansi (protein terlarut) pada ekstrak batang nanas yaitu dengan cara 0,5 ml seri ekstrak enzim kasar ditambahkan dengan 2,5 ml reagen Bradford, kemudian divortex lalu di inkubasi pada suhu ruang selama 10-60 menit. Absorbansi Larutan sampel protein selanjutnya diukur absorbansinya pada $\lambda 595 \mu \mathrm{m}$ (Bradford et al., 1976).

\section{Penentuan pH Optimum Enzim Bromelin}

Sebanyak $0,125 \mathrm{~mL}$ gelatin ditambahkan dengan $0,5 \mathrm{~mL}$ buffer asam fosfat $1 \mathrm{M}$ (pH 6,5) dan 0,125 gram ekstrak kasar enzim bromelin, kemudian diinkubasi pada suhu $65^{\circ} \mathrm{C}$ selama 10 menit pada berbagai nilai $\mathrm{pH}$ pada temperatur optimum yang diperoleh 
(Kumaunang et al, 2011). Variasi nilai pH yang digunakan adalah 4,0; 5,0; 6,0; 7,0; 8,0. Reaksi dihentikan dengan pemanasan pada air mendidih selama 10 menit dan di lakuakan sebanyak 3 kali pengulangan serta absorbansinya diukur pada $\lambda 595 \mathrm{~nm}$.

Penentuan kadar protein ditentukan dengan membandingkan absorbansi ekstrak enzim bromelin dengan persamaan linear kurva standar gelatin. Sedangkan aktivitas enzim bromelin dapat ditentukan dengan rumus di bawah ini:

$$
\text { Aktivitas Enzim }=\text { Substrat Terhidrolisis } \times \frac{1}{\text { BM Enzim }} \times \frac{\text { Volume Larutan }}{\text { Berat Enzim }}
$$

Dimana : BM Enzim $=181.19 \mathrm{~g} / \mathrm{mol}($ Christy et al, 2012)

\section{HASIL DAN PEMBAHASAN}

\section{Pengukuran Kadar Protein Enzim Bromelin pada Variasi 10-60 \% Amonium Sulfat}

Pengukuran kadar protein enzim bromelin dari ekstrak batang nanas yaitu dengan perlakuan batang nanas yang telah di saring dan ditambahkan larutan ammonium sulfat dengan variasi $10 \%, 20 \%, 30 \%, 40 \%, 50 \%$ dan $60 \%$ kemudian diinkubasi agar enzim bromelin mengendap. Adapun kadar protein yang diperoleh pada pengendapan ammonium sulfat ini dapat dilihat pada tebel 1.

Tabel 1. Kadar Protein Enzim Bromelin dari Ekstrak Batang Nanas pada Variasi Konsentrasi Amonium Sulfat.

\begin{tabular}{|c|l|l|l|l|l|l|}
\hline $\begin{array}{l}\text { Konsen } \\
\text { trasi } \\
(\%)\end{array}$ & $\begin{array}{l}\text { U1 } \\
(\mathbf{n m})\end{array}$ & $\begin{array}{l}\text { U II } \\
(\mathbf{n m})\end{array}$ & $\begin{array}{l}\text { U III } \\
(\mathbf{n m})\end{array}$ & $\begin{array}{l}\text { Jumla } \\
\mathbf{h} \\
(\mathbf{n m})\end{array}$ & $\begin{array}{l}\text { Rata- } \\
\mathbf{r a t a} \\
(\mathbf{n m})\end{array}$ & $\begin{array}{l}\text { Kadar } \\
\text { Protein } \\
(\boldsymbol{\mu g} / \mathbf{m l})\end{array}$ \\
\hline 10 & 0,995 & 1 & 1,007 & 3,002 & 1,000 & 36,988 \\
\hline 20 & 0,996 & 1,009 & 1 & 3,005 & 1,001 & 37,023 \\
\hline 30 & 1,016 & 0,991 & 1,005 & 3,012 & 1,004 & 37,107 \\
\hline 40 & 0,995 & 1 & 1 & 2,995 & 0,998 & 36,904 \\
\hline 50 & 0,996 & 0,995 & 0,989 & 2,98 & 0,993 & 36,726 \\
\hline 60 & 1,016 & 0,993 & 1,06 & 3,069 & 1,023 & 37,785 \\
\hline
\end{tabular}

Keterangan:

$\mathrm{U} 1=$ ulangan $1 . \mathrm{U} 2=$ ulangan $2 . \mathrm{U} 3=$ ulangan 3 


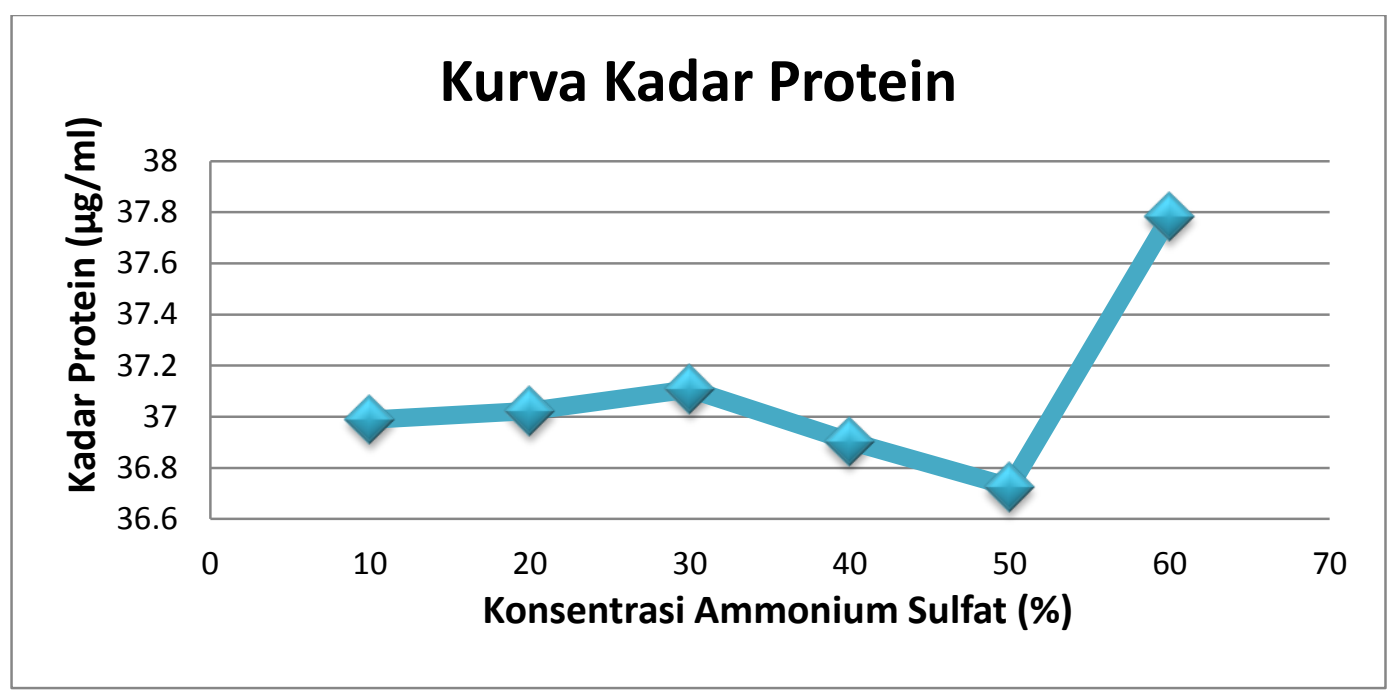

Gambar 3.1. Grafik Pengaruh Konsentrasi Amonium Sulfat terhadap Pengendapan Protein Enzim

\section{Pengukuran Aktivitas Enzim pada Variasi pH}

Aktivitas enzim bromelin dari batang nanas diukur berdasarkan kemampuannya dalam menghidrolisis substrat gelatin. Pengukuran dilakukan secara spektrofotometri pada panjang gelombang $595 \mathrm{~nm}$. Hasil dapat dilihat pada tabel 2 .

Tabel 2. Pengukuran Aktivitas Enzim Bromelin dari Ekstrak Batang Nanas pada Variasi pH

\begin{tabular}{|c|c|c|c|c|c|c|}
\hline $\mathbf{p H}$ & $\begin{array}{c}\mathbf{U} \text { I } \\
\mathbf{( n m})\end{array}$ & $\begin{array}{c}\mathbf{U} \text { II } \\
(\mathbf{n m})\end{array}$ & $\begin{array}{c}\mathbf{U} \text { III } \\
\mathbf{( n m})\end{array}$ & $\begin{array}{c}\text { Rata-rata } \\
(\mathbf{n m})\end{array}$ & $\begin{array}{c}\text { Substrat } \\
\text { terhidrolisis } \\
(\mathbf{g r} / \mathbf{m l})\end{array}$ & $\begin{array}{c}\text { Aktivitas } \\
\text { Enzim (U/gr) }\end{array}$ \\
\hline 4 & 1,000 & 1,001 & 0,999 & 1 & 36,964 & 1,020 \\
\hline 5 & 1,007 & 0,996 & 0,998 & $10,003,333$ & 36,976 & 1,020 \\
\hline 6 & 1,004 & 1,000 & 1,000 & $10,013,333$ & 37,011 & 1,021 \\
\hline 7 & 1,003 & 1,000 & 0,999 & $10,006,667$ & 36,988 & 1,020 \\
\hline 8 & 1,000 & 0,999 & 0,999 & 0,9993333 & 36,940 & 1,019 \\
\hline
\end{tabular}

Proses isolasi dilakukan untuk mendapatkan ekstrak kasar enzim bromelin. Pada penelitian ini enzim bromelin kasar diisolasi dari batang nanas (stem bromelin). Enzim bromelin merupakan tergolong enzim protease sulfhidril yang dapat menghidrolisa protein menghasilkan asam amino sederhana yang larut dalam air. Sisi aktif enzim bromelin ini mengandung gugus sistein dan histidin yang penting untuk aktivitas enzim tersebut. Sehingga enzim ini secara khusus memotong ikatan peptida pada gugus karbonil seperti yang ditemukan dalam arginin atau asam amino aromatik yaitu 
fenilalanin atau tirosin (Gautam et al., 2010). Enzim bromelin ini menghidrolisis ikatan peptida di bagian tengah rantai peptida, sehingga digolongkan endopeptidase.

Apabila ekstrak kasar enzim bromelin telah diperoleh, maka protein dapat diuji secara kuantitatif dengan menggunakan spektrofotometer pada panjang gelombang 595 $\mathrm{nm}$. Digunakan panjang gelombang $595 \mathrm{~nm}$ karena pada penentuan panjang gelombang maksimum pada gelatin (coomassine) didapat bahwa panjang gelombang maksimumnya $595 \mathrm{~nm}$ (Azhari, 2010). Dari hasil pembacaan spektrofotometer tersebut diperoleh kurva standar gelatin dengan persamaan regresi $\mathrm{y}=0,028 \mathrm{x}-0,035$. Digunakan gelatin sebagai larutan standar, karena asam amino utama dari gelatin yaitu glisin dan histidin yang dihubungkan dengan ikatan peptida (Junioanto, et al, 2006).

\section{Pengukuran Kadar Protein Enzim Bromelin pada Variasi 10-60 \% Amonium Sulfat}

Penentuan kadar protein enzim bromelin dilakukan dengan menggunakan metode Bradford dan gelatin sebagai standar. Pada batang nanas memiliki jumlah protein tertinggi dibandingkan bagian yang lain pada tanaman nanas dan termasuk bagian bonggolnya (Gautam, 2010). Amonium sulfat berfungsi untuk mengendapkan protein bromelin tanpa ikut mengendapkan protein nonbromelin. Selain itu ammonium sulfat juga berfungsi menghasilkan peningkatan kemurnian bromelin (Soares et al., 2013).

Pengendapan dengan amonium sulfat dapat dilakukan pada konsentrasi 10-100 $\%$. Semakin tinggi konsentrasi amonium sulfat maka pengendapan protein semakin baik namun pengendapan dengan amonium sulfat terdapat titik kejenuhannya. Oleh karena itu pada penelitian ini menggunakan konsentrasi 10-60\%, karena pada konsentrasi $60 \%$ $100 \%$ maka pengendapannya semakin berkurang dikarenakan larutan protein mengalami titik kejenuhan (Soares, et al. 2010)

Kadar protein akan terus meningkat sejalan dengan peningkatan konsentrasi garam ammonium sulfat, tetapi apabila konsentrasi garam ditingkatkan terus, maka kelarutan protein akan turun. Hal ini sesuai dengan hasil pada penelitian ini, dimana pada konsentrasi 20\%-30\% kadar protein semakin meningkat, sedangkan pada konsentrasi ammonium sulfat $40 \%$ dan $50 \%$ kadar protein menurun. Pada konsentrasi garam yang lebih tinggi protein akan mengendap, sehingga diperoleh kadar protein 
tertinggi pada konsentrasi $60 \%$ dengan kadar protein 37,785 $\mu \mathrm{g} / \mathrm{ml}$, karena pada konsentrasi ini kelarutan protein akan berkurang hingga minimum sehingga protein mengendap.

Pengendapan ini terjadi karena proses persaingan antara garam dan protein untuk mengikat air. Grup ion pada permukaan protein menarik banyak molekul air dan berikatan dengan sangat kuat. Amonium sulfat yang ditambahkan ke dalam larutan protein akan menyebabkan tertariknya molekul air oleh ion garam. Hal tersebut disebabkan ion garam memiliki densitas muatan yang lebih besar dibandingkan protein. Kekuatan ionic garam pada konsentrasi tinggi semakin kuat sehingga garam dapat lebih mengikat molekul air. Menurunnya jumlah air yang terikat pada protein menyebabkan gaya tarik menarik antara molekul protein lebih kuat bila dibandingkan dengan gaya tarik menarik antara molekul protein dan air (mempertinggi interaksi hidrofobik), sehingga protein akan mengendap dari larutan atau berikatan dengan kolom hidrofobik (Wirahadikusumah, 2001). Hasil penelitian ini sesuai dengan hasil penelitian yang dilakukan oleh (Kumaunang et al, 2010) yaitu kadar protein tertinggi enzim bromelin pada penambahan amonium sulfat $60 \%$, dengan nilai sebanyak $0,039 \%$.

\section{Pengukuran Aktivitas Enzim Bromelin pada Variasi pH}

Perlakuan $\mathrm{pH}$ memiliki pengaruh terhadap aktivitas enzim bromelin yang diperoleh. Hal ini menunjukkan bahwa kondisi optimum enzim bromelin diperoleh pada $\mathrm{pH}$ 6,0 dengan aktivitas 1,021 U/gr dengan substrat terhidrolisis sebesar 37,011 gr/ml yang selanjutnya mengalami penurunan pada $\mathrm{pH} 7$ dan $\mathrm{pH}$ 8. Hal ini terjadi karena adanya pengaruh oleh konsentrasi ion $\mathrm{H}^{+}$, atau dengan kata lain, derajat keasaman dari pelarut yang mengelilingi protein enzim bromelin. Dalam $\mathrm{pH}$ yang tepat, perubahan ionisasi gugus ionik enzim pada sisi aktif akibatnya konformasi enzim lebih efektif dalam mengikat dan mengubah substrat menjadi produk sehingga aktivitas enzim mengalami penurunan yang menyebabkan enzim bromelin sudah tidak aktif.

Menurut Nielsen et al., (1999), pH optimum merupakan $\mathrm{pH}$ saat gugus pemberi dan penerima proton yang berperan penting pada sisi katalitik enzim atau pada sisi pengikat substrat berada dalam tingkat ionisasi yang diinginkan, sehingga substrat lebih 
mudah berinteraksi dengan sisi katalitik enzim. Enzim tertentu mempunyai kisaran pH optimum yang sangat sempit di sekitar $\mathrm{pH}$ optimum enzim yang stabilitasnya tinggi. Dalam hal ini enzim yang sama seringkali $\mathrm{pH}$ optimumnya berbeda, karena tergantung dari sumber enzim tersebut (Winarno, 1986).

Hasil penelitian ini sesuai dengan hasil penelitian sebelumnya yang dilakukan oleh (Wuryanti, 2004) dimana $\mathrm{pH}$ optimum dari enzim bromelin yaitu berkisar antara pH 6-8. Kemudian menurut (Winarno, 1986) yaitu aktivitas bromelin optimumnya pada pH 6 sampai 7 dimana enzim akan mempunyai konformasi yang mantap dan aktivitas maksimal. Menurunnya aktivitas enzim pada $\mathrm{pH} 7$ dan $\mathrm{pH} 8$ pada penelitian ini sama dengan hasil penelitian yang dilakukan oleh (Kemaunang et al, 2011). Penurunan aktivitas enzim dari pH 7,0 sampai pH 8,0 terjadi karena lingkungan di sekitar sisi aktif enzim mengalami kekurangan jumlah proton.

Enzim bromelin bersifat hidrolase, yaitu enzim yang bekerja dengan adanya air. Protein mengandung asam amino bersifat hidrofilik, yaitu protein yang residu asam aminonya bersifat menyukai air. Hal ini disebabkan dengan adanya gugus hidrogen pada peptida yang merupakan molekul organik polar, sehingga akan membentuk air dengan adanya gugus $\mathrm{OH}$.

\section{KESIMPULAN}

1. Kadar protein hasil ekstraksi dari batang nanas berdasarkan variasi ammonium sulfat yeng semakin tinggi konsentrasi ammonium sulfat semakin banyak kadar protein enzim bromelin dari batang nanas yang diendapkan yaitu pada konsentrasi $60 \%$ dengan kadar protein tertinggi 37,785 $\mu \mathrm{g} / \mathrm{ml}$.

2. Aktivitas enzim bromelin yang di ekstrak dari batang nanas yaitu pada $\mathrm{pH} 6$ yang merupakan aktivitas tertinggi atau aktivitas optimumnya dengan aktivitas 1,021 U/g.

\section{SARAN}

Sebaiknya enzim bromelin yang diperoleh dari batang nanas dilanjutkan dengan pengujian bioremediasi pada limbah protein, seperti limbah dari pabrik tepung. 


\section{DAFRAR PUSTAKA}

Azhari, azmi. 2010. Penentuan Kadar Protein Dengan Metode Bradford. Institut Pertanian Bogor. Bogor.

Bradford, M. M.. A rapid and sensitive method for the quantitation of microgram quantities of protein utilizing the principle of protein-dye binding. Anal Biochem University of Georgia, 1976. (20 April 2013). Georgia

Chrysty, Meilty Ishak. 2012. Pengaruh Proses Pengeringan dan Imobilisasi Terhadap Aktivitas dan Kestabilan Enzim Bromelain dari Buah Nenas (Ananas comosus (L) Merr). Jurusan Teknologi Pertanian Fakultas Pertanian Universitas Hasanuddin Makassar. (18 Januari 2013). Makassar.

Edahwati, Luluk. 2011. Aplikasi Penggunaan Enzym Papain Dan Bromelin Terhadap Perolehan Vco. Cet. 1. UPN Press. Jakarta.

Effendi, Arnela Meida, Winarni, Woro Sumarni.Optimalisasi Penggunaan Enzim Bromelin Dari Sari Bonggol Nanas Dalam Pembutan Minyak Kelapa. Indonesia Journal Of Chemical Science (1) (2012). http://journal.unnes.ac.id/sju/index.php/ijcs. (11 Januari 2013).

Gautam., S.S., Mishra, S., Dash, V., Amit, K. and Rath, G. Comparative study of extraction, purification and estimation of bromelain from stem and fruit of pineapple plant. India: Thai J. Pharm. Sci. 34, 2010. (20 April 2013).

Fajrin, Eni. 2012. Penggunaan Enzim Bromelin Pada Pembuatan Minyak Kelapa (Cocos Nucifera) Secara Enzimatis. Skripsi. Universitas Hasanuddin. Makassar.

Hairi, Muhammad. 2010. Pengaruh Umur Buah Nanas Dan Konsentrasi Ekstrak Kasar Enzim Bromelin Pada Pembuatan Virgin Coconut Oil Dari Buah Kelapa Typical (Cocos nucifera L.) skripsi. Jurusan Kimia Fakultas Sains Dan Teknologi Universitas Islam Negeri Maulana Malik Ibrahim Malang. (15 Januari 2013). Malang

Indrawati, Tanti. 1992. Pembuatan Kecap Keong Sawah dengan Menggunkan Enzim Bromelin. Balai Pustaka dan Media Wiyata. Semarang.

Junianto, Kiki Haetami dan Ine Maulina. 2006. Produksi Gelatin dari Tulang Ikan dan Pemanfaatannya Sebagai Bahan Dasar Pembuatan Cangkang Kapsul. Universitas Padjadjaran. Bandung.

Kumaunang, Maureen dan Vanda Kamu. Aktivitas Enzim Bromelin Dari Ekstrak Kulit Nenas (Anenas comosus). 200 Jurnal Ilmiah Sains Vol. 11 No. 2, Oktober 2011. (15 Januari 2013).

Nielsen, et al. Electrostatics in in the active site of an $\alpha$-amylase. Eur. J. Biochem., 246, 816-824, 1999. (10 Mei 2013).

Soares, Paulo et al., Studies on Bromelain Precipitation by Ethanol, Poly (Ethylene Glycol) and Ammonium Sulphate. Brazil: Universidade de São Paulo, 2010. http://www.method-of-bromelai-extraction.pdf. (19 Mei 2013).

Suhermiyati, sri dan Sylvia Josephina setyawati. Potensi Limbah Nanas untuk Peningkatan Kualitas Limbah lkan Tongkol sebagai Bahan Pakan Unggas. ANIMAL PRODUCTION, September 2008, hlm. 174-1 78 ISSN 141 1 - 2027 Terakreditasi No.56lD11<TI/I<epl2005. Vol. 10. No. 3. Purwokerto: Fakultas 
pertenakan universitas jenderal sudirman, 2008. http://www.adobe.com/10307174178.pdf. (11 Januari 2013).

Syamsiah. 2006. Taksonomi Tumbuhan Tinggi. Universitas Negeri Makassar. Makassar. Utami, Dhiah Putri, Pudjomartatmo dan Adi Magna Patriadi Nuhriawangsa. Manfaat Bromelin dari Ekstrak Buah Nanas (Ananas comosus L. Merr) dan Waktu Pemasakan untuk Meningkatkan Kualitas Daging Itik Afkir. Sains Peternakan Vol. 9 (2), September 2011: 82-87. ISSN 1693-8828.

Winarno, F. G. 1986. Enzim Pangan. Gramedia. Jakarta.

Wirahadikusumah, Muhammad. 2001. Biokimia Protein, Enzim dan Asam Nukleat. ITB. Bandung.

Wuryanti. Isolasi Dan Penentuan Aktivias Spesifik Enzim Bromelin Dari Buah Nanas (Ananas Comosus L.). No. Artikel: JKSA. Vol. VII. No.3 Desember 2004. Semarang: Fakultas Matematika Dan Ilmu Penegetahuan Alam UNDIP, 2004. http://www.adobe.com/3327-7158-1-SM.pdf. (11 Januari 2013). 